\title{
Pelillistäminen ja digitaaliset pelit työelämän kehittämismenetelminä
}

\author{
$+y$ \\ Pelillistäminen ja digitaaliset hyötypelit saavat sijaa \\ työelämän kehittämismenetelminä. Säilyykö suomalaisessa \\ työelämän kehittämisparadigmassa keskeinen laajojen \\ osallistumismahdollisuuksien arvo?
}

\section{$\boldsymbol{y}$}

PELIT JA PELILLISYYS eli pelin piirteiden hyödyntäminen eri yhteyksissä, ovat nousseet kasvavan kiinnostuksen kohteiksi digitalisaation etenemisen myötä. Ilmiön näkyvin osa on viihdepeliteollisuuden satojen miljardien eurojen arvoinen globaali liiketoiminta. Suomalaiset yritykset ovat menestyneet viihdepeliteollisuudessa. Sen sijaan hyötypeliteollisuus (serious games) on vasta kehkeytymässä oleva ala. (Serious Gaming Cluster Finland ry 2016.)

Eniten hyötypelejä ja pelillistettyjä hyötysovelluksia käytetään terveysteknologiassa. Niillä pyritään tyypillisesti edistämään otollista terveyskäyttäytymistä niin sanottua houkuttavaa (persuasive) teknologiaa hyödyntäen. Toinen vahvassa kasvussa oleva pelillistämisen (gamification) alue on opetus ja oppiminen, jolla hyötypelejä ja pelialustoja on sekä tarjolla että käytössä yhä enemmän.

Sen sijaan digitaalisten pelien hyödyntäminen suomalaisen työelämän kehittämisessä, kuten työhyvinvoinnin edistämisessä, on edelleen harvinaista, eikä aiheesta ole paljoakaan tutkimuksia (Vahlo ym. 2015). Kuitenkin esimerkiksi johtamisen arviointiin ja kehittämiseen on rakennettu Tampereen yliopiston, Turun yliopiston ja Työterveyslaitoksen yhteistyönä digitaalinen hyötypeli JoPe, jonka kehittämiseen osallistuin. Se kerää dataa niin työpaikan kuin tutkimuksenkin käyttöön. JoPessa johtaja saa erilaisia pelissä eteen tulevia tehtäviä suorittamalla palautteena johtamis- 
DigitAALISTEN PELIEN

JA PELILLIST $\ddot{A M I S E N}$

MAHDOLLISUUKSIA

TYÖPAIKOILLA PIDET $\ddot{A} \ddot{A} N$

MONINAISINA.

profiilinsa. Se antaa monipuolista tietoa pelaajasta johtajana ja osoittaa kohtia, joissa kehittyminen voisi olla tarpeen. Pelatessaan johtaja saa reaaliaikaista palautetta siitä, painottuvatko hänen johtamisratkaisuissaan esimerkiksi hyvinvointinäkökohdat vai taloudelliset seikat.

Toisessa JoPen osiossa, minipelissä, pelaaja voi määritellä ihannetyöpäivänsä piirteitä valitsemalla esimerkiksi työmatkan pituuden, työskentely-ympäristön, yhteisön ja työtehtävät. Näin saadaan tietoa työhön liitetyistä ihanteista ja unelmista niin yksittäisille työpaikoille kehittämisen tueksi kuin yhteiskunnan työpoliittisessa päätöksenteossa hyödynnettäväksi. Pelin tuottaman datan avulla tutkijat voivat esimerkiksi vertailla ennakoidun tulevaisuuden työn piirteitä ja pelaajien ihanteellisina pitämiä työn piirteitä. Näin voidaan tarkastella, muuttuuko työelämä ihmisten itsensä hyväksi kokemaan suuntaan. Tällöin myös ihannetyö ja hyvä työn tulevaisuus tulevat määritellyiksi pikemminkin työtä tekevien kuin asiantuntijoiden toimesta. (Järvensivu ym. 2017.)

Vaikka Suomesta on vähän esimerkkejä digitaalisista työhön liittyvistä hyötypeleistä, kansainvälisessä tarkastelussa kokonaisten digitaalisten pelien ja pelillistämisen mahdollisuuksia työpaikoilla pidetään moninaisina. Esimerkiksi spesifien digitaalisten pelien tai pelillistettyjen ohjelmistojen ja palvelujen ohella työprosessien ja työkulttuurien pelillistämisessä on havaittu potentiaalia. Työpaikan ja työprosessien onnistuneelle pelillistämiselle on laadittu tutkimusperustaisia periaatelistauksia (Oprescu ym. 2014), ja pelillisen organisaation piirteistä on kehitetty teoreettinen malli (Warmelink 2011).

Ylipäänsä peleistä tuttuja piirteitä soveltamalla on pyritty tukemaan ja innostamaan erilaisten palvelujen käyttöä, lisäämään käyttäjän aktiivisuutta, motivaatiota, sosiaalista vuorovaikutusta tai toimenpiteiden laatua ja tuottavuutta. Pelillistämisestä on odotettu myös seuraavan sukupolven markkinointimenetelmää. Tutkijatkin ovat hiljalleen kiinnostuneet pelillistämisestä, ja aihetta käsittelevien julkaisujen määrä on kasvussa. Pelillistämisellä on tutkimusten mukaan myönteisiä vaikutuksia, mutta ne riippuvat suuresti sekä ympäristöstä että käyttäjistä. Monet tutkimukset niin ikään tarkastelevat hyötyjä lyhytaikaisesti, jolloin ei voida sulkea pois uutuudenviehätyksen merkitystä. (Hamari ym. 2014.)

Pelillistäminen ja hyötypelit ovat siten kokonaisuudessaan varsin uusi ja jäsentymätön tutkimusalue, työelämäpeleistä puhumattakaan. Suomessa pelillistämiseen on kohdistettu kuitenkin niin paljon odotuksia, että Porin yliopistokeskukseen on perustettu maailman ensimmäinen pelillistämisen professuuri. Aihepiiriin perehtyminen lieneekin ajankohtaista myös suomalaisen työelämän kehittämisen ja aikuiskasvatuksen näkökulmasta. Erityisesti näillä aloilla toimivia kutsuu mukaan keskusteluun se, että kriittisissä, työelämäpeleihin kohdistuvissa tarkasteluissa on vaadittu nostamaan arvoja ja etiikan pohdintaa näkyvälle paikalle, kun pelillisyyttä sovelletaan työelämässä (Raftopoulos 2014). Pelit ja pelillistäminen ovat menetelmällisiä lähestymistapoja ja välineitä, eivätkä itsessään hyviä tai pahoja. Niiden käyttöä ohjaavat arvot ja ideaalit ovat siten ratkaisevia, kun arvioidaan pelien merkityksiä ja vaikutuksia työpaikoilla ja yhteiskunnassa.

\section{TYÖELÄMÄPELIT JA TYÖELÄMÄN KEHITTÄMISEN ARVOPOHJA}

Tarkasteluni kohde ovat kehkeytymässä olevat pelilliset työelämän kehittämismenetelmät ja erityisesti työelämäpelit. Pohdin ensinnäkin, millaisia ne ovat tai voisivat olla, jos lähtökohdaksi otetaan yhtäl̈lä pelitutkimuksen tuottama tieto ja toisaalta työelämän pelillisiä piirteitä koskevat tutkimukset.

Toiseksi suhteutan digitaalisten työelämäpelien soveltamisprosessia työelämän kehittämisen keskeiseen arvopohjaan. Johdan arvopohjan suomalaiseksi työelämän kehittämisen malliksi tai paradigmaksi nimetystä kehittämisen tavasta, joka on toki saanut huomattavasti vaikutteita vähintään pohjoismaisesta 
SUOMALAISEN TYÖELÄMÄN

KEHITTÄMISESSÄ KESKEIST $\ddot{A}$

ON OLLUT TUOTTAVUUDEN

JA TYÖHYVINVOINNIN

YHT ̈̈AIKAINEN KEHITT ̈̈MINEN.

kehittämisen tavasta (Alasoini 2011 ja 2017). Käytän 'suomalaisen työelämän kehittämisparadigman' käsitettä ottamatta kantaa paradigman mahdolliseen erityislaatuun tai omaperäisyyteen.

Suomalaisen työelämän kehittämistoiminnan keskeinen arvo ja ajatus on ollut tuottavuuden - tuloksellisuuden, innovatiivisuuden - ja työelämän laadun - työhyvinvoinnin - yhtäaikainen kehittäminen työpaikoilla. Olennainen osa tämän genren kehittämistoiminnasta liittyi 1990-luvulla ja 2000-luvun ensimmäisellä vuosikymmenellä silloisin työelämäohjelmiin. (Alasoini 2011 ja 2017.) Niistä myönnettiin rahoitusta tietyt kriteerit täyttäville kehittämishankkeille, mikä oli omiaan juurruttamaan ohjelmien ideaalit työelämän kehittäjien käytännöiksi ja orientaatioiksi ja samalla yhtenäistämään kehittämisen tapaa ja sen taustalla vallitsevaa arvomaailmaa. Samassa hengessä Suomessa lanseerattiin vuonna 2012 laaja, tulevaisuusvirittynyt kansallinen työelämän kehittämisstrategia Työelämä 2020, joka on edelleen voimassa (Työelämän kehittämisstrategia vuoteen 2020).

Vahva panostus työelämän kehittämiseen on synnyttänyt työelämän kehittäjien ammattikunnan. Konsulttien ja kouluttajien ohella kehittajjiin lukeutuu huomattava joukko tutkijataustaisia henkilöitä, ja usein puhutaankin tutkimusavusteisesta kehittämisestä tai toimintatutkimuksesta. Hiljalleen on syntynyt myös alan koulutusta, kuten Tampereen yliopiston työn ja hyvinvoinnin maisteriohjelma, jota toteutetaan myös Porin yliopistokeskuksessa.

Vaikka kehittäjiä ja kehittämisotteita on paljon (esim. Ramstad \& Alasoini 2007), huomattava osa jakaa työelämäohjelmien rahoituskriteereillä vahvistaman, suomalaiseksi työelämän kehittämisparadigmaksi nimitetyn ajatuksen hyvästä kehittämisen tavasta, menetelmällisestä ideaalista. Siinä on pidetty keskeisenä laajaa osallistumista ja henkilöstön ja johdon välistä dialogia, jotta turvataan erilaisten intressien ja näkökulmien esiin pääsy. Lisäksi tarvitaan johdon ja henkilöstön välistä demokraattista dialogia. (Alasoini 2011.)

Tutkimuskohteeni on vielä epämääräinen johtuen sen uutuudesta, ja osin se piiloutuu liikesalaisuuksien verhon taa. Oma sijaintini on työelämäpelikehitysalan sisäinen, sillä olen siirtynyt kehittämään ja soveltamaan digitaalisia työelämäpelejä ja pelillistämistä toimittuani pitkään työelämän kehittäjänä muita menetelmiä käyttäen. Artikkelini ei kuitenkaan pohjaudu empiriaan eikä omiin kokemuksiini kehittäjänä esimerkiksi toimintatutkimuksen hengessä, vaikka kentän katsominen sisältäpäin epäilemättä näkyy niin aiheen valinnassa kuin sen käsittelyssä. Sekä digitaalisten työelämäpelien tarkastelu että aihepiiriä koskeva kirjallisuus nimittäin johtavat miettimään, kulkeutuuko tutuksi tullut suomalainen kehittämisparadigma kehittämismenetelmiin, jotka kiinnittyvät toisesta kulmastaan globaalisti virittyneeseen peliteollisuuteen, vai syntyykö pelilliseen kehittämiseen omat ideaalinsa.

Koska työelämäpelien kenttä on uusi, käyn ensin läpi pelillistämistä ja hyötypelejä. Niiden pohjalta hahmottelen, mitä ovat erityisesti digitaaliset työelämäpelit sekä mitä pelillisyys ja pelillistäminen tarkoittavat ja voisivat tarkoittaa suomalaisen työelämän kehittämisessä. Toiseksi pohdin ja analysoin, millaisia vaiheita ja seikkoja tulisi arvioida digitaalisissa työelämäpeleissä ja pelillisyyttä hyödyntävässä työelämän kehittämisessä erilaisten intressien ja tavoitteiden esiin pääsyä turvaavien laajojen osallistumismahdollisuuksien näkökulmasta. Tavoitteeni on virittää keskustelua työelämäpeleistä ja niihin linkittyvistä ajatusmalleista, arvoista ja ideaaleista sekä tarjota kehikko, jonka avulla on mahdollista arvioida osallistumismahdollisuuksien toteutumista työelämäpelien kehitysprosesseissa.

\section{PELILLISTÄMINEN JA HYÖTYPELIT}

Työelämäpelit ovat hyötypelejä, sillä ne pyrkivät ennemmin hyötyyn kuin viihdyttämiseen. Hyötypelit tähtääät määritelmän mukaan jonkin sellaisen edistämiseen, josta on hyötyä myös pelin ulkopuolella 
(Leväsluoto ym. 2016). On tosin esitetty, että hyötypeleissäkin miellyttävyys, innostavuus ja viihdyttävyys ovat keskeisiä piirteitä, eikä viihde- ja hyötypelien välille ole syytä vetää tiukkaa rajaa esimerkiksi työhyvinvointia pelillisin keinoin edistettäessä. (Vahlo ym. 2015.)

Hyötypelien ja pelillistämisen erokaan ei ole aivan selvä. Sitä on kuitenkin mahdollista luonnehtia niin, että hyötypelillä viitataan kokonaiseen pelattavissa olevaan peliin ja pelillistämisellä vain pelin piirteiden tai elementtien käyttöön ei-pelillisessä kontekstissa. Joskus pelillistämistä ja pelisuunnitteluakin (game design) käytetään synonyymeina. (Deterding ym. 2011.)

Pelillistettäessä pyritään integroimaan esimerkiksi digitaalisiin palveluihin, ohjeistuksiin tai oppimisalustoihin piirteitä ja elementtejä, jotka tekevät niistä yhtä houkuttavia ja motivoivia kuin pelit ja synnyttävät vastaavia kokemuksia ja käyttäytymistä kuin pelit. Usein perimmäinen tavoite on saada aikaan jonkinlainen muutos ihmisen käyttäytymisessä.

Olennaista pelillistämisessä on yhtäältä systeeminen lähestymistapa, pelin piirteiden, pelimekaniikkojen ja -dynamiikkojen hyödyntäminen ja toisaalta kokemuksellisuus, pelillistämisen kohteesta syntyvä pelillisyyden kokemus. (Warmelink 2011; Huotari \& Hamari 2012, Ängeslevä 2014; Hamari ym. 2014.) Kokemuksellisuus pelillisyyden kriteerinä tarkoittaa sitä, että peliksi nimitetty tuntuu peliltä ja on tunnistettavissa peliksi kulttuurisen ymmärryksen nojalla.

Jos pelillistäminen määritellään pelin houkuttelevien, jopa koukuttavien, piirteiden siirtämiseksi toisenlaiseen kontekstiin, pitää tietää, mistä pelin houkuttavuus syntyy. Tutkijat ovatkin yrittäneet tavoittaa niitä tekijöitä, jotka tekevät pelistä pelin: saavat aikaan innostusta ja toistuvaa pelaamista. (Deterging ym. 2011.)

Pelin olemuksen tavoittaminen on kuitenkin osoittautunut vaikeaksi. Jaakko Stenros (2014) on lähestynyt asiaa analysoimalla erilaisia pelin määritelmiä ja kiinnittänyt erityistä huomiota siihen, millaisista asioista määritelmissä ollaan eri mieltä, eli mihin määrittelijät kokevat tarvetta ottaa kantaa asemoidessaan itsensä pelitutkimuksen kentässä. Stenros listaa kahdeksan kohtaa.
1. Sääntöjen merkitys: Erityisesti matematiikkaan pohjaavassa peliteoriassa pelin ajatellaan olevan yhtä kuin sen säännöt. Sääntöjen korostamisen vastapooli on valinta ja valinnanvapaus.

2. Systeeminen artefakti vai toimintaa: Pelien määritelmissä harvoin nähdään pelien olevan sekä materiaa että elettyä tapahtumaa ja toimintaa. Yleensä valitaan jompikumpi näkökulma.

3. Erillinen vai yhteydessä: Pelit voidaan ajatella erillisiksi ympäröivästä maailmasta, jolloin niiden tapahtumat eivät vaikuta todellisuuteen. Toisaalta pelit on mahdollista nähdä sosiaalisina kohtaamisina tai prosesseina, jolloin niillä on kulttuuriset juurensa ja ne myös tuottavat dynaamisesti uutta ympärilleen. Niin ikään pelejä voi nähdä todellisuuden representaatioina, esimerkiksi simulaatioina.

4. Pelaajan rooli: Pelaajista käytetään joskus muita nimityksiä, kuten päätöksentekijät tai osallistujat. Joissakin määritelmissä pelaajaa ei mainita lainkaan.

5. Tarkoitus: Peliä voidaan pitää itsetarkoituksena, kuten viihdykkeenä tai taiteena, tai välineenä, kuten hyötypelit.

6. Tuottavuus: Joissain määritelmissä lähdetään siitä, että pelit eivät tuota. Hyötypeleissä tuottavuus on yleensä vahvasti läsnä.

7. Kilpailu ja konflikti: Kilpailu tai konflikti liitetään hyvin usein peleihin, mutta ei välttämättä.

8. Maali ja lopputulokset: Jotkin pelit päättyvät voittoon tai tappioon, toiset päämäärän saavuttamiseen. On myös pelejä, joilla ei ole varsinaista päätepistettä eikä aina selkeää alkupistettäkään. Ideana voi olla pitää peli käynnissä, kuten virtuaalilemmikin kasvattamispeleissä.

Toisinaan pelin elementteihin lasketaan itsensä esittäminen virtuaalisten hahmojen, avatarten, muodossa tai aikapaine. Elementtien on todettu vaihtelevan eri peligenrejen välillä, eikä vain peleille tyypillisiä elementtejä ole kyetty luettelemaan. Voidaankin todeta, että peli on monimutkainen yhdistelmäkäsite, ja pelisuunnittelun elementtejä on mahdollista erotella useilta tasoilta. (Deterging ym. 2011.) Pelien epämääräisyys tekee myös työelämäpelien määrittelystä hankalaa. 


\section{HUOMION KIINNITTÄMINEN}

\section{VAIN MOTIVAATIOTA JA}

HOUKUTTAVUUTTA LIS $\ddot{A} \ddot{V I I N}$

PELILLISIIN ELEMENTTEIHIN

ON KAPEA KATSANTO.

Käytännössä hyötypelikehityksessä pyritään tyypillisesti lisäämään käyttäjän motivaatiota esimerkiksi pisteillä, tulostaulukoilla, merkeillä, edistymistä osoittavilla tasoilla, tarinoilla, teemoilla, maaleilla, palautteella, palkinnoilla, edistymisen osoittamisella sekä haasteilla. Oppimisessa pelillistämisen on todettu tuottavan enimmäkseen myönteisiä vaikutuksia, kuten lisäävän motivaatiota, tehtäviin sitoutumista ja innostumista sekä nautintoa. Kielteisinä vaikutuksina on mainittu lisääntynyt kilpailu ja hankaluudet tehtävien arvioinnissa. (Hamari ym. 2014.)

\section{PELIN KONTEKSTIN HUOMIOIMINEN}

Vaikeudet pelin houkuttavuuden lähteen löytämisessä koskevat oletettavasti pelin kontekstin merkitystä. Pelin sisäiset piirteet ovat vain osa pelaajalle muodostuvaa kokemusta. Pelitutkimusta onkin kritisoitu pelin ja pelaamisen kontekstuaalisten ja kulttuuristen tekijöiden vähättelemisestä ( O 'Donnell 2014). Useat hyötypelejä ja pelillistämistä koskevista tutkimuksista ovat nimittäin kvantitatiivisia ja keskittyvät motivoivien tekijöiden etsintään ja vertailuun. Laadullisten tutkimusten kautta kuva pelillistämisestä on vähitellen rikastunut. (Hamari ym. 2014.)

Erityisesti strukturalistiset pelitutkimukset keskittyvät pelin rakenteellisiin tekijöihin, elementteihin. Konstruktionistiset tutkimukset taas kiinnittävät huomiota pelin, pelaamisen ja pelaajan väliseen vuorovaikutukseen: pelin piirteiden korostetaan olevan sosiokulttuurisesti rakentuneita, ja pelin määritelmien ajatellaan olevan sidoksissa aikaan ja paikkaan ja siksi vaihtuvia. Konstruktionistisesta lähtökohdasta pelillistämisen määrittely pelillisten elementtien lisäämiseksi ei-pelilliseen ympäristöön vaikuttaa tyhjältä. (Genvo 2014.) Samalla käy selväksi, että sama työelämäpeli tuottaa eri kokemuksen eri työntekijöille, koska pelikokemus muodostuu vuorovaikutuksessa.

Niin strukturalistisissa kuin konstruktionistisissakin pelitutkimuksissa pelaamisen laajempi kehys jää kuitenkin edelleen vähälle huomiolle. Kontekstin merkitystä pelin kokemukselle korostavassa kritiikissä onkin painotettu, että peli, pelaaminen ja pelin tuottamat tilanteet ja hetket tapahtuvat aina tietyssä ympäristössä, jossa ne koetaan ja jossa ne saavat merkityksensä. Pelin koko systeemi on vahvasti kiinnittynyt laajempaan systeemiin. Siksi merkitys ja merkityksellisyys syntyvät sekä pelin designista että pelin roolista ympäristössään. Peli voi myös heijastella ympäristöään, kuten paikallista kulttuuria. ( $\mathrm{O}$ 'Donnell 2014.) Kontekstuaalisesti ymmärrettynä monella työpaikalla käytetty työelämäpeli saa viime kädessä merkityksensä ja osoittaa käyttökelpoisuutensa kullakin työpaikalla erikseen, eivätkä merkityksenannot ja vaikutukset ole välttämättä kaikkialla samanlaisia.

Pelien ja pelillistämisen kontekstin yhä parempaa ymmärtämistä niin sosiaalisessa ja systeemisessä mielessä kuin käyttäjän mukaan ottamisen mielessäkin pidetään tärkeänä pelitutkimuksen tulevaisuuden tehtävänä (Hamari ym. 2014). Työelämäpeleissä konteksteja on useita. Kontekstin ja pelaajan huomioiminen tarkoittaa, että työpaikan käytännöt ja rakenteet otetaan sekä pelillisen kehittämistoiminnan lähtökohdaksi että päätepisteeksi. Pelin sekä siihen osallistuvan henkilöstön työn arjen ja työhön liittyvien kokemusten ja työprosessista nousevien intressien kytkennät tulisi kuitenkin pitää riittävässä määrin esillä koko pelillisen kehittämisprosessin ajan. (ks. Järvensivu 2018.)

Vastaavasti suomalaisen työelämän kehittämisparadigman ideaalin mukainen työelämäpelien käyttö edellyttäisi laajaa kehittämiseen osallistumista ja koko henkilöstön yhteistä kehittämistyötä. Sillä tavoitellaan niin ikään kunkin työpaikan ominaispiirteiden huomiointia ja eri henkilöstöryhmien intressien ja äänen kuulemista. Kehittämisparadigman ideaalin mukainen kehittäminen on siten pelitutkimuksen näkökulmasta työelämäpelin kontekstin huomioimista. 
Tavoite täydentyy työelämäpelikehitystyössä konstruktionistisen pelitutkimuksen näkökulmalla pelaajan ja pelin välisestä vuorovaikutuksesta eli pelaajan osallisuudesta ja osallistumisen mahdollisuuksista pelissä. Samoin se täydentyy luonnollisesti strukturalistisilla katsannoilla pelin sisäisistä motivoivista ja houkuttavista piirteistä.

Kun otetaan huomioon pelitutkimuksen kontekstuaalinen kritiikki ja työelämän kehittämisparadigman arvomaailma, on selvää, että huomion kiinnittäminen työelämäpeleissä ja pelillisessä työelämän kehittämisessä vain motivaatiota ja houkuttavuutta lisääviin pelillisiin elementteihin, kuten pisteisiin, tasoihin ja vertailutaulukoihin, jää kapeaksi katsannoksi. Työelämäpelin työpaikan kokonaistilanteessa, työprosessissa ja intressiasetelmissa saamat merkitykset jäisivät kokonaan huomiotta, mikä saattaisi olennaisella tavalla vaikuttaa siihen, miten peli työpaikalla koetaan ja millaisia tavoiteltuja hyötyjä sillä olisi mahdollista saavuttaa.

\section{LUONTAINEN PELILLISYYS TYÖSSÄ JA TYÖPAIKOILLA}

Pelin ja pelaamisen kontekstia voidaan lähestyä myös pelillistämisen resurssina. Pelisuunnittelussa korostetaan tällöin niitä seikkoja ja dynamiikkoja, joilla kohderyhmä jo luontaisesti pelillistää toimintaa omiin intresseihinsä, motivaatiotekijöihinsä ja arvoihinsa pohjaavin tavoin. (Jensen 2012.)

"Luontaista pelillistämistä" löytyy työpaikoilta. Pelillisyys ja pelaaminen ovat vuosikymmeniä kuuluneet osaksi työelämää niin hyvässä kuin pahassa. Työn sosiologiassa, erityisesti teollisuussosiologiassa, on tehty perusteellisia analyysejä ja klassisia tutkimuksia esimerkiksi teollisuustyöntekijöiden salaisista urakkapeleistä ja tehtaiden pelidynamiikoista, joilla työntekijät tuottavat suostumustaan työprosessiin (Burawoy 1979 ja 1985). Tehdastyössä työntekijöillä on ollut tapana kehitellä "pelejä" rutiininomaisen työn synnyttämistä tylsyyden kokemuksista selvitäkseen, mutta peleillä on ollut myös muita, esimerkiksi sosiaalisen arvonannon saavuttamista koskevia, tavoitteita (Järvensivu 2007). Työväen historian tutkimuksessa työpaikkapeleistä kirjoitetaan Suomessa edelleen silloin tällöin (Fingerroos ym. 2015), mutta tutkimusta aiheesta voisi luonnehtia marginaaliseksi. Asiaa selittää osaksi se, että päästäkseen käsiksi työväestön omaan tietoon tutkijan on saavutettava jonkinlainen sisäpiiriläisyys, mikä taas edellyttää varsin pitkäaikaista läsnäoloa työpaikalla (mt.; Järvensivu 2007).

Työntekijöiden omien pelien ottaminen kehittämistoiminnan lähtökohdaksi ei ole uusi ajatus. Pelillisten dynamiikkojen selvittämistä on käytetty suomalaisen työelämänkehittämisparadigman arvojen suuntaisessa kehittämistyössä avaamaan syitä sille, miksi kehittämis- ja koulutusponnistukset työpaikalla ovat epäonnistuneet. Esimerkiksi ikkunatehtaan pelilliseen dynamiikkaan perehdyttiin sen selvittämiseksi, miksi työntekijöiden monitaitoisuuden kehittäminen oli epäonnistunut vuosia kestäneistä yrityksistä huolimatta. Vaikka työkierto ja laajempi tehtävien opettelu olisi ollut suositeltavaa työterveyden ja osaamisen laajentamisen näkökulmista, eikä kukaan avoimesti kiistänyt niiden mielekkyyttä, työnantajan monitaitoisuuden lisäämisyritykset kilpistyivät ikkunatehtaan työntekijöiden hiljaiseen vastarintaan. (Järvensivu 2007; Järvensivu 2011.)

Kun tehtaan pelillinen dynamiikka oli selvitetty, monitaitoisuuden vastustaminen tuli ymmärrettäväksi. Monitaitoisuus ja tehtäväkierto olisivat rikkoneet tehtaan toimintaa ja sen työprosesseja olennaisesti jäsentävän työprosessin pelillisen dynamiikan: toiminnan kannalta välttämättömän epävirallisen organisoitumisen tavan motivaatiorakenteineen, toiminnan tiloineen ja mielekkyyden lähteineen. Mikäli työntekijät olisivat omaksuneet uuden toimintatavan, koko toimintaa jäsentävä ja työn mielekkyyttä tuottava dynamiikkakin olisi pitänyt rakentaa uusin tavoin. Se taas olisi tarkoittanut laajoja ja perustavia systeemisiä muutoksia niin kulttuurissa, ajattelutavoissa kuin toimintakäytännöissäkin. (Mt.)

Pelillistämistä esiintyy toki muunlaisissakin työympäristöissä, ja digitalisaation edetessä työntekijöiden pelaamat pelit ovat saaneet osin virtuaalista luonnetta. Laajassa selvityksessään Vahlo ym. (2015, 31) ovat todenneet, että varsinaisia digitaalisia viihdepelejä pelaa työpaikalla vähintään toisinaan noin viidennes Suomen työmarkkinoilla olevista työikäisistä, 
DigitaAlisia VIIHDEPELEJ $\ddot{A}$

PELAA TYÖPAIKALLA

NOIN VIIDENNES

TYÖMARKKINOILLA OLEVISTA

TYÖIK ̈̈ISIST $\ddot{A}$.

useimmat oma-aloitteisesti. Digitaalisen pelaamisen taustalta löytyy samankaltaisia motivaatiotekijöitä kuin vuosikymmenten takaisten tehdaspelien analyyseissa (esim. Järvensivu 2007). Työntekijät tavoittelevat digipelien pelaamisella esimerkiksi rentoutumista, viihtymistä ja työstä irtautumista. (Vahlo ym. 2015.)

Työelämäpelejä kehittävät ja soveltavat tahot kuitenkin rakentavat digitaalisten pelien arvolupaukset yleensä sen varaan, että pelit toimivat insentiivinä toivottuun käyttäytymiseen tai yhteisöllisyyden lisääänä. Viihdepelit ja hyötypelit ovatkin jääneet irralleen toisistaan määrittyen jopa toistensa vastakohdiksi, minkä katsotaan johtaneen turhaan katsannon kaventumiseen. (Mt.)

Luontaista pelillistämistä työpaikalla on kuitenkin mahdollista pitää yhtenä pelillisen työelämän kehittämisen potentiaalisena muotona. Tällöin työelämän kehittämisen pelilliset menetelmät on mahdollista jakaa kolmeen:

1. luontaisen pelillisyyden hyödyntämiseen,

2. pelillistämiseen ja

3. varsinaisten työelämäpelien kehittämiseen ja käyttöön.

Ensimmäisessä tapauksessa työelämän kehittämistoimissa hyödynnetään työpaikoilla olevaa pelillisyyttä, pelaamista ja pelillisiä dynamiikkoja, joita saattaa sisältyä esimerkiksi palkitsemisjärjestelmiin. Luontainen pelillistäminen ei tyypillisesti ole digitaalisessa muodossa, lukuun ottamatta digitaalisten viihdepelien itseisarvoista pelaamista työajalla (Vahlo ym. 2015).

Dynamiikkojen huomiointi tarkoittaa työprosessista kumpuavien intressien, näkökulmien ja kamppailujen huomioon ottamista, mikä vahvistaa laajan osallistumisen ajatusta (Järvensivu 2018). Kun dynamiikat on löydetty, voidaan pohtia, onko niissä jotain, jonka varaan rakentaa pelillisyyttä hyödyntäviä kehittämistoimia tai voisiko löydöksiä hyödyntää digitaalisen pelillistämisen tai pelikehityksen pohjana. Olemassa olevien pelillisten dynamiikkojen käyttö pelikehityksen pohjana liittää luontaisen pelillistämisen samalle jatkumolle pelillistämisen ja työelämäpelien soveltamisen kanssa.

Toinen pelillisen työelämän kehittämisen menetelmä on pelillistäminen. Se tarkoittaa pelillisten piirteiden, kuten pisteiden keruun, tasoihin perustuvan etenemisen tai tarinallisuuden, lisäämistä esimerkiksi työpaikan johtamis- tai aloitejärjestelmään tai kehityskeskusteluinstrumentteihin. Apuna voidaan käyttää tarvittaessa pelillistämisen asiantuntijoita.

Kolmas tapa on kehittää työpaikalle omia kokonaisia työelämäpelejä tai käyttää olemassa olevia pelejä, kuten JoPe. Viihdepelien ja oppimispelien sekä näitä varten rakennettujen digitaalisten alustojen käyttämistä ei myöskään kannata sulkea pois. Tällaisia ovat esimerkiksi Seppo, Action Track ja Kahoot!

\section{TYÖELÄMÄPELIEN POTENTIAALIT JA RISKIT}

Työelämäpeleistä ja pelillisestä työelämän kehittämisestä ei juuri ole suomalaista tutkimusta. Edes kapeammin työhyvinvointia edistävistä digitaalisista peleistä ja pelillisistä sovelluksista ei ole saatavilla liiemmin tutkimustietoa. Tilannetta selittää ensinnäkin se, että digitaaliset pelit ja pelilliset ratkaisut ovat tyypillisesti organisaatioiden sisäisiä ja niiden omaan ongelmanratkaisuun liittyviä eli kontekstisidonnaisia.

Toiseksi kaupalliset sovellukset ovat usein osa palveluntarjoajien portfoliota, josta ne räätälöidään osaksi kokonaisratkaisuja. Pelejä ja niiden sisältöjä myös varjellaan rahanarvoisina liikesalaisuuksina. Kolmanneksi toimiala on vielä erittäin nuori, eikä sovelluksia juurikaan ole markkinoilla. (Vahlo ym. 2015.) Neljänneksi syyksi lisään hyötypelien sisällön kehittämisen työläyden, joka on merkittävämpi pullonkaula ja kustannuserä kuin pelin digitaalinen ja graafinen toteutus. Viidenneksi alan kehitystä hidastaa pelikehittäjien ja työelämänkehittäjien välinen kulttuurinen kuilu. 
PelillistäMINEN VOI

K ̈̈̈̈TY Ä HOUKUTTELEVIEN

TEKNOLOGISTEN TEMPPUJEN

KOKOELMAKSI.

Kannattaako digitaalisten työelämäpelien vähäisyyttä sitten harmitella? Oppimispelien tutkimuksessa on tuotu esiin digitaalisen pelillistämisen myönteiset vaikutukset oppimiselle ja motivaatiolle, ja samoja vaikutuksia on mahdollista tavoitella työpaikoilla. Pelaaminen voi parantaa mielialaa, nostaa aktivaatiotasoa ja saada aikaan flow-tilan. Pelien ja simulaatioiden avulla voidaan opettaa monia työelämässä tarvittavia taitoja, kuten johtamista. (Pan ym. 2006; Wood 2009.)

Onkin esitetty, että pelillistetty työ voisi olla myönteinen ja innovatiivinen ratkaisu nykyisiin työpaikoilla koettuihin ongelmiin, kuten psykososiaaliseen kuormitukseen, turhautumisen tunteisiin, vähentyneeseen yhteisöllisyyden kokemukseen ja heikentyneeseen lojaalisuuteen sekä nopeisiin muutoksiin (Oprescu ym. 2014; Vahlo ym. 2015). Kenties pelillisyys toisi helpotusta myös lisääntyneeseen inaktiivisuuteen eli liikkumattomuuteen, johon taukoliikuntapelit, kuten Cuckoo Workout, tai viihdepeleistä Pokemon Go ja oppimispeleistä esimerkiksi Seppo ja Action Track ovat luoneet lupauksia.

Ei-digitaalista pelillistämistä ja pelejä on toisinaan käytetty työelämän kehittämisessä esimerkiksi organisatoristen prosessien saattamiseen yhä inspiroivammiksi ja sitouttavammiksi. Leväsluoto ym. (2016) sovelsivat ei-digitaalista pelillistettyä kehittämismenetelmää muutosten toteuttamisen tueksi sairaalaympäristössä. He totesivat, että roolin vaihtoon perustunut menetelmä innosti ja antoi osallistujille työkaluja organisaation systeemisen ymmärryksen kehittymiseen ja dialogin paranemiseen. (Leväsluoto ym. 2016.)

Kattavan, erityisesti Pohjois-Amerikan markkinoita luotaavan, kartoituksensa pohjalta Vahlo ym.
(2015) ovat jakaneet työhyvinvointipelien mahdolliset ja tavoitellut vaikutukset primaareihin, sekundaarisiin ja tertiaarisiin.

Primaareissa tavoitteenasetteluissa pelaamisella on itseisarvo. Sen uskotaan vaikuttavan innostavasti, auttavan työstä irtautumiseen ja rentoutumiseen, tuottavan onnistumisen kokemuksia sekä kehittävän kognitiivisia taitoja, kuten muistia, luovuutta ja tarkkaavaisuutta. Sekundaarisissa tavoitteenasetteluissa pelaamisella on välinearvo, ja sitä käytetään kannustimena. Pelaamalla pyritään edistämään terveitä elämäntapoja, työpaikkaliikuntaa, työn laatua, asenteita ja työtehoa, osaamista, turvallisuutta tai työn arviointia. Tertiaarisissakin tavoitteenasetteluissa pelillä on välinearvo, kun tavoitellaan yhteisöllisyyttä ja organisaation ja työyhteisön etua. Tällä hetkellä suomalaisilla työpaikoilla pelaaminen ei Vahlon ym. mukaan yleensä tapahdu työnantajan aloitteesta, vaan se on työntekijöiden omaehtoista, primaarivaikutuksiin tähtäävää toimintaa. (Vahlo ym. 2015.)

Työhyvinvointipeleissä painotetaan harvoin pelikokemusta, kuten viihtymistä. Sen sijaan kilpailullisuus korostuu, mitä voidaan pitää riskinä, sillä kilpailua lisäävien pelillisten elementtien ei ole aina todettu tuottavan kehittämiseltä toivottuja vaikutuksia. Paremmuusjärjestykseen asettaminenkin saatetaan kokea kiusalliseksi. Työhyvinvointipelit profiloituvatkin Vahlon ym. näkemyksen mukaan työntekijöiden omaehtoisesta pelaamisesta selvästi erilliseksi toiminnoksi, jossa pelien olemassaolon oikeutusta ei etsitä viihtymisestä vaan työntekijöiden ja työyhteisöjen tehokkuuden lisäämisestä. (Vahlo ym. 2015.) Huomio puoltaa eri näkökulmien esiin pääsyä turvaavien toimintamallien ja arviointikehysten rakentamista työelämäpelikehityksen tueksi.

Arvoja on tärkeä pohtia, koska pelillistämisen on kritiikissä esitetty sisältävän samoja riskejä kuin muiden kehittämisen ja johtamisen menetelmien, jos ne pohjaavat kestämättömään arvomaailmaan.

Pelillistäminen voi kääntyä houkuttelevien teknologisten temppujen kokoelmaksi, joka on omiaan intensivoimaan eli voimaperäistämään työtä, tai se voi sisältää pakko-osallistamista, mikä taas asettuu peleihin liitettyä vapaaehtoisuuden ideaalia vastaan.

Monet digitaaliset pelit kerryttävät dataa, jonka käyttötarkoitusta osallistujat eivät välttämättä tiedä. 
PelaAmisessa KorostuU

PELIN JA PELAAJIEN

VUOROVAIKUTUSSUHDE. mahdollisuuksia työelämän kehittämistoiminnan kannalta uudenlaisissa tapauksissa, joissa kehitetään digitaalinen pelillistetty sovellus tai peli.

\section{LAAJOJEN OSALLISTUMISMAHDOLLISUUKSIEN IDEAALI TYÖELÄMÄPELIEN TAPAUKSESSA}

Työelämän kehittämiseen digitaalisten työelämäpelien Pelit voivat myös saada aikaan illuusion muutoksesta todellisten muutosten sijasta, jos ne jäävät irralleen kontekstista: työpaikan rakenteista ja dynamiikoista. Yhtä hyvin kuin voimaannuttaa, pelillistäminen saattaa kaventaa joidenkin ryhmien tai yksilöiden toimijuutta, tai ylipäänsä pelaaminen voi jäädä irralliseksi ja epäautenttiseksi toiminnaksi. Näistä syistä arvojen ja etiikan pohdintaa on vaadittu nostettavaksi näkyvään rooliin pelillistettäessä työtä. (Raftopoulos 2014.)

Myös Vahlo ym. (2015) nostavat esiin kysymyksen, missä määrin tai millä menetelmillä pelien hyvinvointihyötyjä tavoitteleva toiminta voisi olla ylhäältä alas johdettua. Työnantajan tulisi asetelmaa välttääkseen ainakin varmistaa erilaisten pelien saatavuus ja ehkäistä pelillisten sovellusten yhdenmukaistamista ja välineellisten hyötyjen korostamista pelikokemuksen sisäisen palkitsevuuden kustannuksella, mikäli tavoitteena ovat pelien motivoivan vaikutuksen takana olevat autonomian, valinnanvapauden, vapaaehtoisuuden ja itsemääräämisen kokemukset. (Vahlo ym. 2015.) Näiden ehdotusten oheen voidaan työelämän kehittämisparadigman valossa nostaa henkilöstön laajan osallistumisen turvaaminen pelikehitysprosessin kaikissa vaiheissa.

Jaoin pelillisten työelämän kehittämismenetelmät 1) jo olemassa olevaan, luonnolliseen, pelillisyyden hyödyntämiseen, 2) pelillistämiseen ja 3) varsinaisten työelämäpelien kehittämiseen tai käyttämiseen.

Kolme menetelmällistä lähestymistapaa muodostavat jatkumon. Työpaikan olemassa olevan pelillisen dynamiikan hyödyntäminen kehittämistoiminnassa lienee menetelmällisesti vähän käytetty mutta jo tunnettu lähestymistapa (ks. Järvensivu 2007). Pelilliseen dynamiikkaan pohjaava kehittäminen ei sinänsä välttämättä edellytä varsinaista pelikehitystä eikä sellaisena poikkea olennaisesti perinteisestä kehittämistoiminnasta. Keskitynkin pohtimaan osallistumis- ja pelillistämisen keinoin liittyvät uhkakuvat nousevat yhtäältä pelitutkimuksessa havaitusta pelien kontekstin heikosta huomioimisesta ja toisaalta erityisesti seikoista, jotka syntyvät nimenomaan työpaikasta ja työprosessista digitaalisen pelillistämisen ympäristönä. Merkittävin uhkakuva nousee siitä, että työelämäpeleihin perustuvaa kehittämistä ohjaavat arvot jäävät pohdinnan ja keskustelun ulkopuolelle. Miten sitten ankkuroida työelämän kehittämismenetelminä käytettävät pelit ja pelillistäminen suomalaisen työelämän kehittämisen mallin arvoihin ja ideaaleihin? Kysymys on keskustelun arvoinen, kun rakennetaan digitaalisten työelämäpelien ja pelillistämisen genreä ja käytäntöjä.

Työelämän kehittämisparadigmaa seuraten henkilöstön laajojen osallistumismahdollisuuksien systemaattinen arviointi ja edistäminen pelillisen työelämän kehittämisen eri vaiheissa vähentää uhkakuvien toteutumisen todennäköisyyttä. Kontekstiinsa asetettuna (pelin kiinnittyminen työprosessiin, työpaikan käytäntöihin ja rakenteisiin sekä ennen että jälkeen pelin käytön) ja konstruktionistisesti ymmärrettynä (pelaajan ja pelin vuorovaikutus ja pelaajan osallistuminen pelin aikana) pelillisestä työelämän kehittämisprosessista on erotettavissa kolme vaihetta. Kriittiset kohdat ovat

1. pelillisen kehittämismenetelmän käyttöön ottaminen (valitseminen tai kehittäminen)

2. valitun tai kehitetyn työelämäpelin käyttäminen (pelaaminen)

3. pelin seuraukset (pelaamisen vaikutukset työhön ja työpaikkaan).

Työelämäpeli on integroitavissa kontekstiinsa, työpaikan arkisiin käytäntöihin ja rakenteisiin, erityisesti kehittämisprosessin alussa ja lopussa, vaikka pelinaikainenkin integroiminen on mahdollista. Osallistumismahdollisuudet turvaavassa kehittämisen tavassa 
työpaikan johto ja henkilöstö voivat tuoda peliin keskeisiksi katsomansa tavoitteet ja piirteet sekä sopia niiden toteutumisesta vaiheessa yksi. On myös mahdollista, että esimerkiksi ulkopuolinen asiantuntija toteuttaa työpaikan luontaisen pelillisyyden analyysin pelikehityksen taustaksi.

Toisessa vaiheessa, pelaamisessa, sen sijaan korostuu pelin ja pelaajien vuorovaikutussuhde.

Kolmannessa vaiheessa, pelaamisen jälkeen, pelillisen kehittämisen vaikutukset ovat jälleen palautettavissa osaksi työpaikan käytäntöjä ja rakenteita. Keskusteluun nousevat pelin tuotosten, kuten kerätyn datan ja siitä tehtyjen päätelmien, seuraukset työpaikalla. Jokaisessa vaiheessa on mahdollista arvioida suomalaisen työelämän kehittämisen mallin toteutumista.

Ensimmäinen kriittinen kohta on heti prosessin alussa, kun päätetään, millaista sovellusta aletaan rakentaa, mihin tarkoitukseen ja keitä otetaan mukaan kehitysprosessiin. Onko tavoitteena parantaa sekä tuottavuutta että työelämän laatua? Toteutetaanko pelillistäminen johdon ja henkilöstön yhteistyönä? Mikäli halutaan noudattaa suomalaisen työelämän kehittämisen mallin periaatteita, niiden tulisi toteutua ja henkilöstön tulisi voida osallistua päätöksiin pelin tavoitteista, peligenrestä ja designista sekä sovellettavista pelillistämisen piirteistä. Ylipäänsä henkilöstön tulisi voida osallistua pelin suunnitteluun ja testaukseen niin paljon ja laajasti kuin mahdollista.

Pelilliset digitaaliset työelämän kehittämismenetelmät poikkeavat aiemmista menetelmistä monin tavoin. Esimerkiksi ulkopuolinen kehittäjä ei välttämättä tuo työpaikalle mukanaan omaa valmista kehittämismenetelmäänsä tai -otettaan, vaan kehittämismenetelmä, peli, on mahdollista rakentaa työpaikalla yhdessä, jolloin kehittämismenetelmän taustaoletukset ja valinnat ovat otettavissa avoimesti keskusteltaviksi. Valmiita pelejä käytettäessä näin ei toki ole, mutta silloinkin ainakin henkilöstön osallistumismahdollisuudet pelin valintaan tulisi huomioida. Esimerkiksi johtamisen arviointi- ja kehittämispeli JoPen kehittämisessä oli mukana viisi organisaatiota, jotka osallistuivat peliosioiden ja -tehtävien ideointiin ja joiden johtajat testasivat pelin kehitysversioita. Koska kehitettiin johtajille suunnattua peliä markkinoille, koko henkilöstöä ei koettu mielekkääksi ottaa mukaan pelikehitystyöhön.

Varsinainen pelaamisvaihe sisältänee eniten uutta ja erilaisia variaation mahdollisuuksia verrattuna perinteisiin työelämän kehittämismenetelmiin, jotka tyypillisesti perustuvat kasvokkaiseen ja ryhmän yhtäaikaiseen läsnäoloon. Pelaamisella voidaan jo sinänsä pyrkiä saamaan aikaan monia työhyvinvoinnin ja tuottavuuden kannalta myönteisiä vaikutuksia, kuten viihtymistä, flow-tilaa, oppimista, yhteisöllisyyden tunnetta, työpäivän aikaista liikkumista ja muita myönteisinä pidettyjä käyttäytymisen muutoksia, jotka mahdollisesti heijastuvat välittömästi työhön. Perinteisiin kehittämismenetelmiin kuuluvissa kehittämiskäytännöissä, esimerkiksi työryhmissä tai työpajoissa, ei tyypillisesti tavoitella vastaavia välittömiä hauskuuden, ilon, uppoutumisen, innostuneisuuden ja viihtymisen kokemuksia, vaikka toki perinteisissä kehittämistilaisuuksissakin voidaan innostua ja ilostua.

Uutta on samoin kehittäminen pääasiassa virtuaalisissa tiloissa ja esimerkiksi mobiililaitetta käyttäen. Digitaalisella yhteisen kehittämisen foorumilla osallistujat ovat läsnä ja osallistuvat mahdollisesti hyvinkin erirytmisesti, mikä sopii turvaamaan eri henkilöstöryhmien osallistumismahdollisuuksia yhä liikkuvammassa työelämässä. Kasvokkaista yhteistoimintaa voidaan niin ikään vahvistaa digitaaliseen läsnäoloon perustuvalla toiminnalla. Laajojen osallistumismahdollisuuksien tavoitteen näkökulmasta olisi kuitenkin kysyttävä, syrjäyttääkö digitaalisuuteen pohjaava kehittämismenetelmä joitain henkilöitä tai ryhmiä osallistumisen marginaaliin tai kokonaan ulkopuolelle.

Digitaalinen peli luo siis uudenlaisen, kasvokkaisuutta ja virtuaalisuutta yhdistävän kehittämisympäristön, jossa niin pelin sisäiset logiikat kuin pelin kytkökset työpaikan todellisuuteenkin ovat monimutkaisia. Osallistumismahdollisuuksien näkökulmasta digitaalinen kehittämisympäristö edellyttää konstruktionistisessa pelitutkimuksessa ja pelikehityksessä kiinnostuksen kohteena olevien pelien sisäisten vaikutusmahdollisuuksien ja vuorovaikutteisuuden arviointia, sillä myös niissä on kyse osallisuuden tunteesta ja osallistumisesta. Tämäkin kuuluu vaiheeseen kaksi, pelaamiseen. 
SYRJ̈̈YTT $\ddot{A} \ddot{A} K O ̈$

\section{DIGITAALISUUTEEN POHJAAVA \\ KEHITT ̈̈MISMENETELMÄ}

JOITAIN HENKILÖIT $\ddot{A}$ TAI

RYHMI ̈̈?

Pohdittavaksi tulee esimerkiksi seuraavanlaisia kysymyksiä: Missä määrin pelaaja voi pelatessaan osallistua pelin kehkeytymiseen ja vaikuttaa sen tuottamiin tuloksiin ja kokemuksiin? Onko pelaajalla valinnanmahdollisuuksia? Voiko pelaaja esimerkiksi valita, mitä osioita tai tehtäviä pelaa ja mitä jättää pelaamatta? Pystyykö pelaaja vaikuttamaan pelin etenemiseen? Voiko pelata uudelleen ja valita toisin? Millaisissa kanavissa pelillinen vuorovaikutus tapahtuu, tekstinä, kuvina, äänenä tai kosketuksena ja onko näissä valinnan mahdollisuuksia? Sisältääkö peli mahdollisuuksia vertailuihin tai keskusteluihin toisten kanssa, ja miten nämä on järjestetty? Voiko pelaaja itse luoda peliin sisältöjä tai antaa palautetta pelistä? Esimerkiksi JoPessa pelaaja voi valita, mitä osioita hän pelaa, milloin ja miten pitkään. Pelin jatko riippuu jossain määrin siitä, millaisia valintoja pelaaja tehtävissä tekee, ja vertailut muiden pelituloksiin ovat mahdollisia.

Kolmannessa vaiheessa, pelaamisen jälkeen, arvioinnin kohteeksi olisi otettava mahdollisuudet osallistua peliä pelaamalla työpaikan käytäntöihin ja niiden kehittämiseen, toisin sanoen yhteydet ja siirtymät pelistä sen ulkoiseen kontekstiin. Miten läheinen tai limittäinen pelin virtuaalinen kehittämistila tai todellisuus on työlle, mukaan lukien lisätty, laajennettu todellisuus, kuten Pokemon Gossa? Mikä merkitys pelillä ja sen pelaamisella on työntekijälle ja hänen työlleen? Muuttaako pelaaminen pelin ulkopuolista todellisuutta työpaikalla ja jos, niin miten? Miten pelin tuotoksia käytetään työpaikalla? Kerääkö peli dataa, ja jos kerää, niin kuka päättää, kuka dataa käyttää ja mihin? Esimerkiksi JoPessa työpaikalla voidaan päättää, millaisia raportointeja pelistä halutaan, ja tulosten pohjalta on mahdollista käynnistää kehittämistoimia. Johtajat taas voivat käyttää pelissä saamiaan johtamisprofillejaan esimerkiksi kehityskeskusteluissa tai rekrytointitilanteissa.

Pelaamisen seurausten vaihetta koskevat myös kysymykset pelaamisen tuottamien myönteisten tai kielteisten kokemusten ja tunteiden siirtymisestä pelin ulkopuolelle, kuten työhön. Pysyykö pelatessa kohonnut aktivaatiotaso, flow-tila tai osallistumisen kokemus yllä, miten kauan se mahdollisesti pysyy, ja onko kokemus työstä vastaava kuin pelissä syntyneet tunteet? Vahvistavatko pelin sisäiset ja sen ulkopuoliset kokemukset osallistumismahdollisuuksista toisiaan vai ovatko ne ristiriidassa?

Pelillisiä kehittämismenetelmiä tulisi arvioida kolmessa kohdassa osallistumisprosessia:

1. osallistumismahdollisuus pelikehitystyöhön, kuten pelin tavoitteista, sisällöistä ja käyttötavoista sopimiseen, tai vaihtoehtoisesti valmiina hankitun työelämäpelin valintaan

- mitä pelillistetään ja kenen intresseistä lähtien

- kenen genreen ja kulttuuriin sopivaksi peli rakennetaan

2. osallistumismahdollisuus pelatessa ja peliä käytettäessä, esimerkiksi sisältöjen tuottamiseen ja juonenkulkuihin vaikuttamiseen

- pelin ominaisuudet, erityisesti vuorovaikutteisuus ja osallistuvuus

- mahdollisuus luoda itse sisältöjä ja tehdä pelin sisäisiä valintoja

3. osallistuminen pelin avulla työpaikan käytäntöjen ja rakenteiden kehittämiseen

- kytkentä tai siirtymä pelin virtuaalitodellisuuden ja työelämän välillä

- siirtymä tai siirtovaikutus kehittämisen kontekstista työhön

- pelin seuraukset työpaikan toiminnalle ja pelaajalle, mukaan lukien datan keräämistä koskevat kysymykset

- pelin merkitys kontekstissaan

Ainakin edellä mainittujen kaltaisia kysymyksiä tulisi pohtia, mikäli käytetään digitaalista pelillistämistä 
tai hyötypeliä työelämän kehittämisessä ja halutaan sällyttää suomalaiseen työelämän kehittämisparadigmaan kuuluva laajojen osallistumismahdollisuuksien arvo ja ideaali. Tarkastelua on varmasti mahdollista täydentää ja tarkentaa tulevissa tutkimuksissa.

\section{PÄÄTELMÄT}

Pyrkimykseni hahmotella pelitutkimuksen ja työelämäntutkimuksen kirjallisuuden pohjalta digitaalisia pelejä ja pelillistämistä työelämän kehittämisen menetelminä tuotti potentiaalisten pelillisten työelämän kehittämismenetelmien jaottelun kolmeen alaryhmään, jotka voivat myös muodostaa jatkumon:

1. työpaikan olemassa olevien luontaisten pelillisten piirteiden ja dynamiikkojen hyödyntäminen

2. pelillistäminen eli pelillisten elementtien ja piirteiden lisääminen

3. kokonaisten työelämäpelien kehittäminen tai valmiiden soveltaminen ja käyttäminen.

Näistä erityisesti digitaalisten pelillistettyjen sovellusten ja digitaalisten pelien hyödyntäminen on työelämän kehittämistoiminnassa varsin uutta ja vähän tutkittua.

Työelämäpelien käytöstä on tunnistettu riskejä, joiden vuoksi on korostettu toimintaa ohjaavien arvojen nostamista avoimeen keskusteluun (Raftopoulos 2014). Tästä syystä toisena tavoitteenani oli pohtia työelämäpelien käyttöä perinteisen suomalaisen työelämän kehittämisparadigman laajan osallistumisen arvon toteutumisen näkökulmasta (esim. Alasoini 2011).

Rakensin artikkelissa alustavan arviointikehyksen vinkkikysymyksineen tukemaan työpaikkojen ja kehittäjien pohdintaa siitä, missä määrin henkilöstön laaja osallistumismahdollisuus toteutuu digitaalisiin peleihin ja pelillistämiseen nojaavassa kehittämistyössä. Sen perusteella arviointia ja osallistumisen vahvistamista tulisi kohdentaa

1. pelikehitystyön tai työelämänpelin valinnan vaiheeseen,

2. pelaamisvaiheeseen sekä
3. niihin "palauttaviin" kytkentöihin, jotka kiinnittävät pelin ja pelaamisen työpaikan käytäntöihin ja rakenteisiin ja saavat aikaan vaikutuksia työpaikalla. Esimerkistä käy pelissä kerätyn datan käyttö.

Ensimmäinen ja kolmas vaihe ovat suoraan sidoksissa pelin ja pelaamisen kontekstin, kuten työpaikan, välisen yhteyden huomioimiseen, mikä on todettu pelitutkimusten katvealueeksi (esim. O 'Donnell 2014). Siten pelitutkimusta ja työelämäntutkimusta yhdistävät jatkotutkimukset aiheesta olisivat tarpeen. Pelin kontekstista nousevat myös mahdollisuudet hyödyntää työpaikoilla jo olemassa olevia pelillisiä piirteitä ja dynamiikkoja, joiden tutkimus on jäänyt työelämäntutkimuksen marginaaliin mutta saattaisi olla hyödyllistä työelämäpelien kehittämisen ja tutkimuksen näkökulmasta.

Pelaamisen vaihe taas kiinnittyy konstruktionistiseen pelitutkimukseen, jossa kiinnostuksen kohteena on pelin ja pelaajien vuorovaikutus (esim. Genvo 2014). Työelämän kehittäjillä olisi opittavaa pelikehittäjiltä ja pelitutkimuksen tuloksista. Maastoa ei kuitenkaan ole kartoitettu pelitutkimuksenkaan suunnasta, sillä sekä pelillistämisen kontekstin yhä parempaa ymmärtämistä sosiaalisessa ja systeemisessä mielessä että käyttäjän mukaan ottamisen mielessäkin on pidetty pelitutkimuksessa tärkeinä tulevaisuuden tutkimuskohteina (Hamari ym. 2014). Esittämäni arviointikehys voi osaltaan auttaa kohdentamaan ja jäsentämään tulevaisuudessa työelämäpelejä koskevia tutkimuksia, jotka asemoituvat työelämän tutkimuksen ja pelitutkimuksen yhteiseen maastoon.

Tarkasteluni perusteella työelämäpeleihin liitetyistä uhkakuvista huolimatta ei ole syytä olettaa, että digitaaliseen pelillistämiseen pohjaavat menetelmät sisältäisivät lähtökohtaisesti vähemmän osallistumisen mahdollisuuksia kuin muukaan kehittämistoiminta. Digitaalisten välineiden etu verrattuna esimerkiksi perinteisiin yhtäaikaista läsnäoloa vaativiin työpajoihin tai kehittämisryhmiin on niiden vähäisempi sidonnaisuus aikaan ja paikkaan sekä erilaisten osallistumisen rytmien ja tapojen salliminen. Työelämän muututtua yhä mobiilimmaksi 


\section{Pelillisten Menetelmien}

\section{VOI OLETTAA TUKEVAN}

OSALLISTUMISTA.

tämän kaltaiset menetelmät voivat tavoittaa henkilöstöä jopa muita menetelmiä laajemmin ja helpommin. Lisäksi peleihin ja pelillisyyteen on rakennettu sisään houkuttelevuus ja motivointi, joten pelillisten menetelmien voisi olettaa tukevan osallistumista.

Valmiudet ja halu käyttää digitaalisia laitteita, sovelluksia ja pelejä voivat kuitenkin olla erilaisia eri henkilöstöryhmillä. Aiemmissa tutkimuksissa eroja on löydetty esimerkiksi sukupuolen ja iän osalta (Koivisto \& Hamari 2014). Työelämäpeleistä on huomautettu, että erilaiset työntekijätyypit suhtautuvat pelillistämiseen ja sen eri osa-alueisiin eri tavoin (Hamari ym. 2014). Pelillistäminen tai hyötypelit niin ikään jakavat mielipiteitä. Niihin liittyy lisäksi paljon tietämättömyyttä, kielteisiä asenteita ja ennakkoluuloja, koska ne ovat toistaiseksi erittäin uusi ja heikosti tunnettu alue (Vahlo ym. 2015).

Tulevaisuudessa olisikin tärkeää sekä huolehtia työelämäpelejä taustoittavien arvojen tarkastelusta ja tätä koskevasta avoimesta keskustelusta että tutkia empiirisesti, jäävätkö tai jättäytyvätkö jotkin henkilöstöryhmät intresseineen digitaalisia pelillisiä kehittämismenetelmiä käytettäessä ulkopuolisiksi ja mikäli jäävät, missä vaiheessa kehittämisprosessia ja miksi.

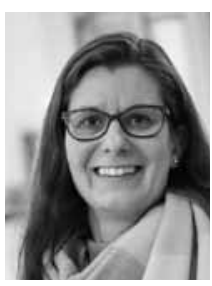

ANU JÄRVENSIVU

FT, yliopistotutkija, sosiologian dosentti Tampereen yliopisto pelillistämisasiantuntija Simppelisti Oy

Tutkimuksen on rahoittanut Työsuojelurahasto. 
Alasoini, T. (2011). Hyvinvointia työstä. Kuinka työelämää voi kehittää kestävällä tavalla? Tykes-ohjelman työraportteja 76. Helsinki.

Alasoini, T. (2017). Työelämän kehittämisstrategiat ja ohjelmat Euroopassa: Mitä Suomi voisi oppia niistä? Työpoliittinen aikakauskirja 60(1), 35-44.

Burawoy, M. (1979). Manufacturing Consent. Changes in the Labour Process under Monopoly Capitalism. Chicago: The University of Chicago Press.

Burawoy, M. (1985). The Politics of Production. Factory Regimes under Capitalism and Socialism. London: Verso.

Deterding, S., Dixon, D., Khaled, R. \& Nacke, L. (2011). From Game Design Elements to Gamefulness: Defining "Gamification". MindTrek 11, September 28-30, 2011, Tampere, Finland.

Fingerroos, O., Naarminen, M. \& Roitto, M. (2015). Äänekäs luokka. Tehdastyöväen menneisyyden ja muistitiedon jäljillä. Työelämän tutkimus 13(3), 209-222.

Genvo, S. (2014). Toward a constructivist ludology: a link between play and game studies. Critical Evaluation of Game Studies seminar. University of Tampere, 28.-29.4.2014.

Hamari, J., Koivisto, J. \& Sarsa, H. (2014). Does Gamification Work? - A Literature Review of Empirical Studies on Gamification. Hawaii Conference on System Science.

Huotari, K. \& Hamari, J. (2012). Defining Gamification - A Service Marketing Perspective. MindTrek 2012, October 3-5, Tampere, Finland.

Jensen, M. (2012). Engaging the Learner: Gamification Strives to Keep the Users Interest. https://www.td.org/ Publications/Magazines/TD/TD-Archive/2012/01/ Engaging-the-Learner-Gamification-Strives-to-Keepthe-Users-Interest.

Järvensivu, A. (2011). Työntekijöiden pelit, pelivarat ja intressien synty. Teoksessa Eteläpelto A., Heiskanen T. \& Collin K. (toim.) Valta ja toimijuus aikuiskasvatuksessa. Aikuiskasvatuksen 49. vuosikirja. Helsinki: Kansanvalistusseura, 140-158.

Järvensivu, A. (2007). Työprosessitieto, avain monitaitoisuuteen. Tampere: TUP.

Järvensivu, A. (2018). Työelämäpelit ja työprosessin hallinnan dynamiikka.

Järvensivu, A., Talola, N., Konu, A., Linna, J., Hella, J., Tiitinen, K., Hakulinen, J. \& Turunen, M. (2017). Tuleeko sote-johtajan ihannetyöpäivästä totta? Työpoliittinen aikakauskirja 3/2017. Työ- ja elinkeinoministeriö, 34-46. http://julkaisut.valtioneuvosto.fi/bitstream/ handle/10024/80814/TEM\%20tyopoliittinen $\% 20$ aikakauskirja\%203_2017.pdf
Koivisto, J. \& Hamari, J. (2014). Demographic differences in perceived benefits from gamification. Computers in Human Behavior 35, 179-188.

Leväsluoto, J., Heikkilä, J., Tuovinen, J. \& Viitanen, K. (2016). Gamification as an Enabler of Mutual Learning in Complex Health Care Systems. International Journal of E-Services and Mobile Applications 8(4), 35-47.

O’Donnell, C. (2014). On Balinese Cockfights: Deeply Extending Play. Critical Evaluation of Game Studies seminar. University of Tampere, 28.-29.4.2014.

Oprescu, F., Jones, C. \& Katsikitis, M. (2014). PLAY AT WORK - ten principles for transforming work processes through gamification. Frontiers in psychology 5(14), 1-5.

Pan, Z., Cheok, A.D., Yang, H., Zhu, J. \& Shi, J. (2006). Virtual reality and mixed reality for virtual learning environments. Computers \& Graphics 30(1), 20-28.

Raftopoulos, M. (2014). Towards gamification transparency: A conceptual framework for the development of responsible gamified enterprise systems. Journal of Gaming \& Virtual Worlds 6(2), 159-178.

Ramstad, E. \& Alasoini, T. (toim.) (2007). Työelämän tutkimusavusteinen kehittäminen Suomessa. Lähestymistapoja, menetelmiä, kokemuksia, tulevaisuuden haasteita. Tykes-ohjelman raportteja 53. Helsinki.

Serious Gaming Cluster Finland ry, työryhmä (2016). Suomen hyötypeliteollisuuden tilannekuva 2016. Loppuraportti. Tekes. https://www.tekes.fi/ globalassets/global/ohjelmat-ja-palvelut/ohjelmat/ skene/hyotypeliteollisuus_2016_loppuraportti_v1_1. pdf.

Stenros, J. (2014). The Game Definition Game: A Review of the Meanings of "Game". Critical Evaluation of Game Studies seminar. University of Tampere, 28.-29.4.2014.

Työelämän kehittämisstrategia vuoteen 2020. http:// www.tyoelama2020.fi/files/35/tyoelaman_ kehittamisstrategia_final.pdf.

Vahlo, J., Ollila, J. \& Koponen, A. (2015). Digitaalinen pelaaminen työhyvinvoinnin edistämisessä. Turku: Turun yliopisto.

Warmelink, H. (2011). Towards a Playful Organizational Culture. Proceedings of DiGRA 2011 Conference: Think Design Play, 1-16.

Wood, R. E. (2009). Simulations, learning and real world capabilities. Education + Training 51(5-6), 491-510.

Ängeslevä S. (2014). Level up: Työrutiinit peliksi. Helsinki: Talentum. 